\title{
Role of Communitization Marketing 3.0 on Purchasing in Higher Education of Postgraduate Institutions in Jakarta
}

\author{
Wilhelmus Hary Susilo*
}

Departement of Postgraduate, Faculty of Economic University of Persada Indonesia Y.A.I,

Diponegoro 74, Central Jakarta, Indonesia

Yudi Yulius

Departement of Postgraduate, Faculty of Economic University of Persada Indonesia Y.A.I, Diponegoro 74, Central Jakarta, Indonesia

\author{
Lili Suryati \\ Doctoral Programme of Postgraduate, Faculty of Economic University of Persada Indonesia Y.A.I, \\ Diponegoro 74, Central Jakarta, Indonesia \\ harry_susilo@hotmail.com
}

\section{Doi:10.5901/mjss.2015.v6n2p125}

\section{Abstract}

A concept conducted from the influence of marketing 3.0 on purchase decisions in post graduate institutions of higher education in Jakarta. Research was conducted the quantitative confirmatory method, of structural equation hybrid modeling. Samples used 105 postgraduate students at three institutions. Research findings showed confirmatory factors analysis (CFA) included; Communitization, and Purchasing, had X2 (222.6 and 546.5), GFI ( .59 and .62) and CFI (.88 and .89). Further more Construct Reliability (CR=.95 and .95), were condaucted reliable construct variables. Marginal fitting hybrid model with, $X 2=$ 20.27, $P$ value $=.00041$, RMSEA $=.156, \mathrm{GFI}=.92, \mathrm{AGFI}=.78$ and $\mathrm{CFI}=.97$. The hypothesis result was influenced communitization marketing 3.0 on the purchasing decision with $t$ value $=9.16$, successfully to confirmed. Finally test between the dimensions' variable and was the most superior and significant was correlated connection between the customer and the dimensions of the situation with a value of $r(e r)=.99$.

Keywords: Purchasing, Marketing 3.0, Superior Dimension.

\section{Introduction}

The role of higher education on post graduate program strategic and having value customers for students in build communities intellectual in Indonesia in the future so institutions post graduate programs have an important role in the efforts to build competitiveness institutions and competitive advantage. Furthermore according to Kotler and Keller (2013) to reach success in the future must marketing to be holistic, build brand stronger through performance than via a promotion and leading electronically as well as through building a system of information and superior communication. Futhermore institution prioritize to focus on customers, and performance institution defined by considering the external factor, namely from target customers which are thruster purchase (Wang and Lo, 2004). Then the management institution of higher education should be aware of the benefits and costs of various orientation marketing, before deciding. The marketing selected orientation will also have a big impact on the allocation of resources, and interested, college segments and the quality of students after graduation. After higher education institutions of a market structure determine offered, post graduated institutions will be useful to the development program profile to consumers can determine market and generic type of post graduated program .(Cravens and Piercy, 2006). In spite of the philosophy concept of marketing (Limakrisna and Susilo 2012) aimed at giving satisfaction to needs and consumers, so can be a philosophy business stating that consumer needs is a requirement economic and social for competitiveness institutions, in order to get profit in the long run.

Customer satisfaction positively connected with an intention repurchase, desire to recommend goods and services, loyalty and also the benefits. In relation to customer loyalty, that if the customers satisfied on goods or quality of service, 
as well as superior value given to consumers, it will improve loyality consumers. The consumer loyalty or allegiance will do the purchase of products reëxamined the same, as well as institutions notify to consumers that other potential, from the words of mouth. As an research result of Curtis et al (2011) discussing overall loyalty of consumers pertaining to significantly to the act of purchasing repeated and level customer satisfaction, when customer satisfaction correlated on purchase. Next so many cases competitiveness higher education institutions the weak at the size competitiveness organization (organizational competitiveness) covers an aspects: (1 ).Work environment less conducive, (2). Design jobs not scheduleling well, (3). Innovation program development magister and learning processes, (4). Management technology applied still not integrated, (5). Management quality of being is still less reliable (6). Indicators a quality that standard. Competitiveness superior institutions could supported by loyality, according to research curtis et al ( 2011 ), stating that loyality and purchase had strong impact and positive. Consumers normally attend a decision purchase, start of the stage understand the need for education, seek for information about instutusi of post graduated program, then do identification and evaluation an alternative program and finally decided one program. From the description the hence to do research regarding: model hybrid an influence marketing 3.0 of the purchasing on institution post graduate program in Jakarta. The formulation of problems in study it consists of a model hybrids: (1). Is there the influence of communitization marketing 3.0 on the purchase of consumers? The objectives of this study and benefit from the research cunducted contributes the empirical and marketing data and information as strategic decision-making for the post graduate instututions with regard to institutional models hybrids that fit and information being valid and significant of dimensions between variables research, furthermore can developed marketing science particularly as marketing 3.0 for the future.

\section{Literature Review}

This section looks at the various definitions of role of communitization marketing 3.0 in higher education and an action of the purchasing from people at large.

\subsection{Role of communitization marketing 3.0 in higher education}

The heart of every busniness was always creating loyal customers, and busniness succeed will be done with getting, keeping and growing customers. Institution in higher education need some students and successful marketing institution in higher education that the top position must customers next in importance from frontline people (Kotler and Keller, 2013). Constomers having the nature of a base as creatures social always interact among consumer products, with the same brands for the sake of some advantage hoped. Consumers with lifestyles on certain brands always connected with the their communities to create a mutual social into a consumer brands group based on the same. The way that they connected can use the social media as well as direct contact on an even was aimed to promote a joint together (Susilo and Yulius, 2013). The consumers' trust according to Kotler and Kartajaya (2010), means reclaim consumer confidence is by embracing the so-called with the new belief system consumers, who are horizontal. Consumers currently collect community itself, will create products and experience them alone and seeks only character who admires outside their community. But after they find it, they would become vassals of the faithful. Consumers getting appreciate: co-creation, communitization, and characters. An important elements keep it in character building was: (1). Respect, (2). Attention, (3). Full responsibility, (4). Knowledge. To keep credibility institution do promotion with advertising, then institution must satisfy a condition reality that be right at between ad with fact the original. In the world of consumer horizontally, lost its credibility mean the loss the grid potential customers, so that will affect the institution forward and sustainable. Next the future marketing is horizontally, not vertical.The future marketing will partly formed by development currently and partly by force the long run. To brand can connecting to human, brand need to develop a dna authentic at the heart of differentiation them. This dna reflect identity brands in social network consumers. Brand with dna unique will continue to build the character. (Kotler and Kartajaya, 2010, p35)

The communitization according to Kotler and Kartajaya (2010), consumers interact and will always connected with the media social who can be against bonds derived from relation of one to one among its members and create a base that was stronger between a fan that loyalty. With an increasing the frequent occurrence of a group of community customers do the joint activity and widely, involving circles of society will be many potential information that can be absorbed widely and ide- a new idea can be created. he impact of the situation of the use of absorptions phenomenon that actual, institutions will be a service business increasingly tough in the face of competition (Susilo and Yulius, 2013). 


\subsection{An action of the purchasing from people at large.}

Consumers had the plan will buy very subjective and full of the uncertainty and have an alternative options on goods and services. Based on research and influence internal and external, marketers often questioned to consumers about intention buy from consumers to could predict sales. Dimensions into focus of marketers to the wishes of consumers in performing an action the purchase includes: (1). The concept products or services delivered on consumers. (2). Situation that could affect the purchase by the consumer. (3). Encouragement purchase by the consumer. (4). An act of purchase by the consumer (Bennett, 2010). According to Kotler and Keller (2013) that purchase decision in executing purchase intention pertain: (1) Brand, (2). Dealer, (3). Quantity, (4). Timing, and (5). Payment method.

\section{Research Methodology}

This research methodology section looks at participants, instrument, framework of theoretical research, and research design that conducted. The reason that have chosen of test hybrid to be assessed confirmatory the level of significance model hybrid that fit with communitization marketing 3.0 and an action of the purchasing science were conducted with structural equation modeling because for latent variables as communitization and purchasing variables (Wijanto2008, Surip 2012, Diposumarto and Susilo 2013).

\subsection{Participants}

Respondents were 105 students, $60 \%$ females and $40 \%$ males, from 3 institution of postgraduate classes from STIK Sint Carolus, UMB and UPI Y.A.I in Jakarta were invited to participate in the study. The average age was 32.86 years with a standard deviation 7.32 from the mean.

\subsection{Instrument}

The instrument used in this study was the questionnaire that conducted base from theoretical research pertain communitization of marketing 3.0 and act of purchasing from comsumer at large.

\subsection{Framework of theoretical research}

Theoretical framework to research on this model became the basis of the development of test hybrid to be assessed confirmatory the level of significance model hybrid that fit and superior in giving the outer covering as input and information for decision-making strategic marketing in the field of higher education institutions in Jakarta. The framework of theoretical research which is developed to become a model hybrid can be seen from figure 1 below:

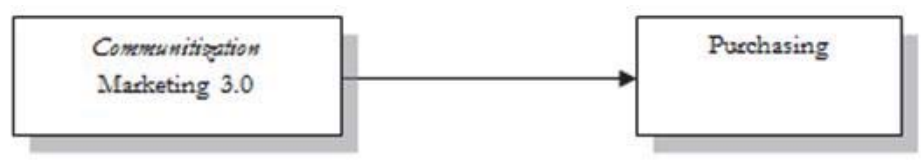

Figure 1. The framework theoretical research was developed to become a model an influence of communitization marketing 3.0 on the act of purchasing in higher education institutions

Based on the study above and the research hypotheses which developed can be seen on a table 1 below and consisting of:

Table 1. Hypothesis of model hybrids research

\begin{tabular}{ll}
\hline No & Hypothesis of model hybrids research \\
\hline 1 & $\begin{array}{l}\mathrm{H}_{1} \text { : There is an influence of communitization marketing } 3.0 \text { on the act of purchasing in institutions post } \\
\text { graduate program in Jakarta. }\end{array}$ \\
\hline
\end{tabular}




\subsection{Research design}

This research conducted on quantitative methods research with an approach design marketing confirmatory research and structural model analysis from a structural equation modeling with analysis of LISREL (Hair, 1998, Wijanto, 2007, Susilo and Yulius, 2013). Thus the dimensions analysis of variable research, according to Ghozali (2006), Diposumarto (2012) and Diposumarto and Susilo (2013) of the test Pearson correlation conducted for exploring value of $r$ (er) for strong and significant on dimensions of one variable were correlated with superior, through matrik test correlation dimensions of research variables. Sample data from population source that were set as sample in this research included of 3 institution of post graduate in Jakarta; STIK Sint Carolus, UMB and UPI Y.A.I in Jakarta, so as to be done generalization population source samples specified (Susilo and Julius, 2013). Technique samples to this research was conducted total sampling of the class post graduate that were taught by researchers at three institutions in Jakarta that included 105 respondents that invited for participated in that study.

\section{Results and Discussion}

Test the validity and reliability instrument of research conduct the validity and reliability by approach once approved, that conducted by of Pearson correlation, included of 30 respondents and results value cronbac's alpha .969, thus the results was very reliable. Analysis univariat and univariat statistic descriptive distribution data respondents successfully obtained covering; the distribution higher education institutions for postgraduate degree, the number of respondents, sex, job, income, average age respondents and standard deviations age, can be seen, tabel. 2 below this:

Table 2. The Distribution Characteristic of Respondents

\begin{tabular}{|c|c|c|c|c|c|c|}
\hline & r education institution & oon & $\overline{\operatorname{Sex}(\%)}$ & Job (\%) & Income (\%) & Avarage of age SD \\
\hline 1 & STIK SINT CAROLUS & 11 & \multirow{3}{*}{$\begin{array}{l}F=60 \\
M=40\end{array}$} & 1. (Lecturer) $=4.8$ & \multirow{3}{*}{$\begin{array}{l}1(\geq 5 \text { Million })=61.9 \\
2(<5 \text { Million })=38.1\end{array}$} & \multirow{3}{*}{32.86} \\
\hline 2 & UMB & 75 & & 2.(Private) $=60$ & & \\
\hline 3 & UPI Y.A.I & 19 & & $\begin{array}{l}\text { 3. }(P N S)=11.4 \\
\text { 4. }(\text { Others })=23.8\end{array}$ & & \\
\hline
\end{tabular}

The distribution of respondents from 3 institutions of higher education in Jakarta that were participated in this research can be seen at figure 2 below this:

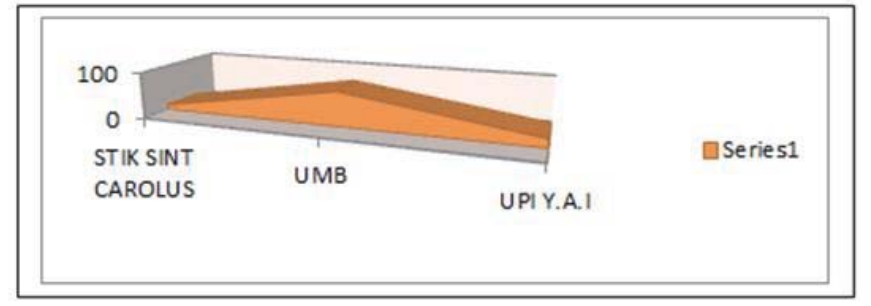

Figure 2. The Higher Education Institutions Postgraduate Distribution of Respondents

The female is more dominant following higher education, by looking table 2 above, as it for job on private sector have 60 $\%$, to level income $(>5 j u t a \mathrm{Rp})=61.9 \%$. Level age participants higher education having value average 32.8 years with $\mathrm{SD}=7.3$. Marketing department on institutions of higher education can do segments market more focus based on data in table 2 above, thus that action plan on a marketing plan be more conducted on target market proper. Describing profile consumers started from program magister market the generic, at the level of profile consumers can describe size and composition in general based on consumers on post graduate program (Cravens and Piercy, 2006). In composition in figure 3, below can show that the prospect consumers derived from among workers private of $60 \%$, therefore conducted for segmented market in the working private can continue to review to made superior marketing plan for higher education at large. 


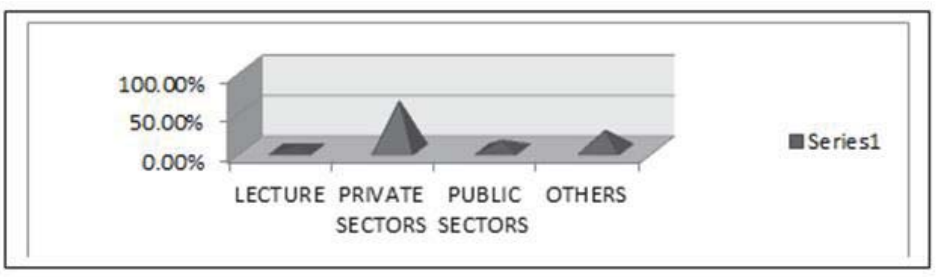

Figure 3. The Higher Education Institutions Postgraduate of Job Respondents Distribution

The results of the analysis of structural equation modeling included; the CFA, test of hybrid, test of fittings model, and test of the hypothesis. An equation (1) mathematical model hybrid can be seen as the following below:

$\eta_{1}=\gamma_{11} \cdot \xi_{1}+\zeta_{1}$

The CFA examined of confirmatory factors analysis includes of variable the study: Communitization Marketing 3.0 $\left(V_{1}\right)$, Purchasing $\left(V_{2}\right)$ the decision of the purchase included; level fitting model can be seen on a table 3 below, and test the validity of and reliability construct can be seen in the description under this:

Tabel 3. Goodness of fit Index of CFA

\begin{tabular}{cccc}
\hline Goodness of fit Index & (Cut of Value) & $\mathbf{V}_{\mathbf{1}}$ & $\mathbf{V}_{\mathbf{2}}$ \\
\hline Chi- square & $<3$ & 222.6 & 546.5 \\
GFI & $\geq 0,90$ & 0.59 & 0.62 \\
CFI & $\geq 0,90$ & 0.88 & 0.89 \\
\hline
\end{tabular}

An out put of CFA variable test included; Communitization Marketing 3.0 and Purchasing can be seen from figure 4 below:
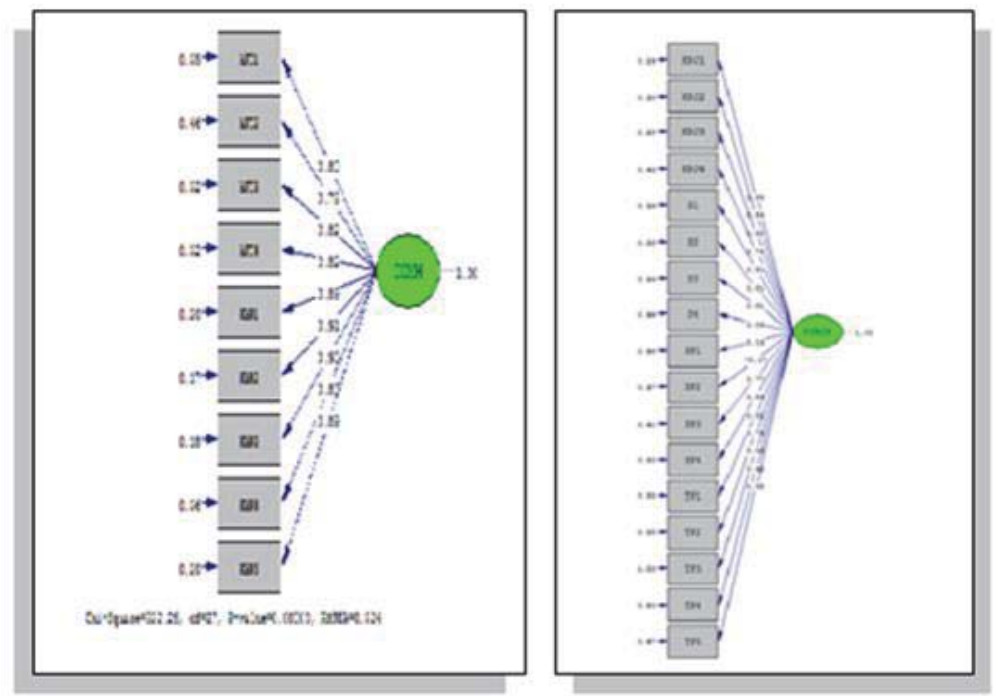

Figure 4. Model CFA of Communitization Marketing $3.0\left(\mathrm{~V}_{1}\right)$ and Purchasing $\left(\mathrm{V}_{2}\right)$

Results of examine for validity and reliability construct include: (1).Indicator that not valid included: $\mathrm{S}_{4}, \mathrm{SP}_{1}, \mathrm{SP}_{2}$, and $\mathrm{TP}_{3}$ (Purchasing variable) and indicators invalid not included partly on the model. (2).Value of reliability variable should have > 0.7 (Wijanto, 2007, Susilo and Julius, 2013), and count the value (construct reliability) ware Communitization Marketing $3.0\left(V_{1}\right)=.95$, Purchasing $\left(V_{2}\right)=.95$, so the entire variable were reliable. The hybrid model fittings examine was results an equation: PURCHASE $=.90^{*} \mathrm{COMM}$, Errorvar. $=.20$. Regarding the model in influence of Communitization Marketing $3.0\left(V_{1}\right)$ on Purchasing $\left(V_{2}\right)$, can be seen figure 5 , below: 


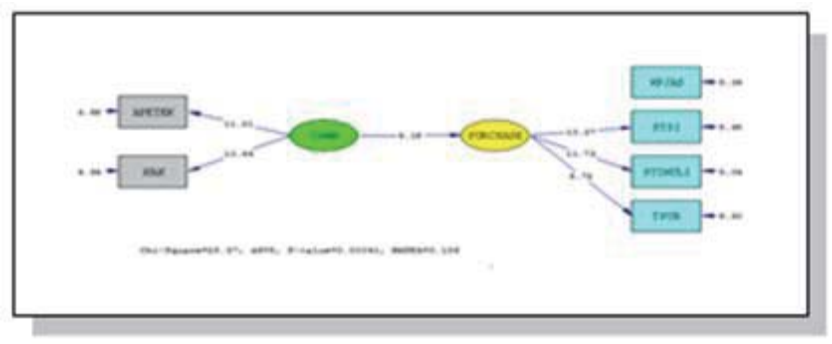

Figure 5, Research Model output of an Influence Communitization Marketing $3.0\left(V_{1}\right)$ on Purchasing $\left(V_{2}\right)$ in higher education institutions

Thus the examine of the research model was the marginal model fitted can be seen at table 4 , below this:

Table 4. Goodness of fit Indeks the Research Model

\begin{tabular}{ccc}
\hline Goodness of fit Indeks & Cut of Value & Research Model \\
\hline x $^{2}$ - Chi- square & $<3$ & 20.27 \\
$\boldsymbol{P}_{\text {value }}$ & $>.05$ & .00041 \\
RMSEA & $<.08$ & .156 \\
GFI & $\geq .90$ & .92 \\
CFI & $\geq .90$ & .97 \\
AGFI & $\geq .90$ & .78 \\
\hline
\end{tabular}

The hypotheses research results examine can be seen by acceptance hypothesis if $t$ value result the outer covering lisrel having value> 2 from predictor variables (Wijanto, 2007, Susilo and Julius, 2013), that can be seen on a table 5 below this:

Table 5. The Results of Hypotheses Examine

\begin{tabular}{cccc}
\hline No & The hypotheses research & Value of $t$ & Description \\
\hline 1 & $H_{1}$. & $t=9.16$ & Confirmed \\
\hline
\end{tabular}

An examination of dimensions between variables dimensions between variables research that influential significantly covering; variable of communitization on variable of purchase, that conducted test bivariat Pearson correlation could be see on a table 6 matrik test below this:

Table 6. An Examine of Dimensions between variables of Communitization and Purchase

\begin{tabular}{ccccc}
\hline & KPJAS & STSI & STIMUL & TPUR \\
\hline APETEK & .979 & .979 & .990 & .994 \\
KAK & .979 & .997 & .990 & .994 \\
\hline
\end{tabular}

The human characteristics according to research findings Viacava and Pedrozo (2010) to the management in higher education complex perspective required human characteristics and the potential which develops upon human thinking as processor automatic data logically to logic that are developed to consider interaction between emotion and cognition and its environment. An orientation marketing higher education institutions according to Wright (2012), literature marketing delineates marketing- four types of orientation colleges and universities should be fully aware of the potential benefits and costs any part of orientation. In orientation marketing a college or university could have a significant impact on all aspects of marketing strategies. Also the research finding with models equation structurally from Meyer, et.al (2013) showed orientation purchase influential is varied on perceptual loyality consumers. Furthermore connect with consumers instant and can communicate be an extraordinary valuable to the institution.(Scott, 2011). Thus the research result conducted from Goebel et al (2013) founded that, indicated a role for back-and-forth communications and a cooperative relational history to enhance the purchasing's reputation. 
Such an the dimensions related to table 6 above, with very closely and significant of variable purchase, with links to so closely and significant having value of $r$ (er) largest $=.997$ to relations dimension connection between consumers/ KAK (of variable communitization) on dimensions situation/ STSI (of variable purchase) the significantly on this research result between variables of communitization marketing 3.0 on an act the purchase on institution of post graduate program in Jakarta, it was in line with the thought of Bennett (2010) that marketers must understand the process that consumers buy goods or services in relation use marketing mix strategy that work. However similarly according to Schiffman and Kanuk (2008), certifying an act of decision making consumers consists of three stages included; the introduction of necessity, research before the purchase and judgment various an alternative then marketing mix being up to date pertain; people, process, program and performance institutions, that according to Kotler and Keller (2013), thus that marketing will work well if people in organization have strong commitment and also reflected marketers can understand consumers with good and broader, not only function as purchase of goods and services. Furthermore an according to Stimac and Simic (2012) strategy of being marketing applicabality to institution of higher education; forming the department marketing- tools marketing should be used to promote institution: publicity, marketing, a web public relations, direct marketing aimed at potential students in current and former student to improve the image and reputation institution of higher education. Next to the improvement of competitiveness institution necessary networking a formal, such as results examine by Kingsley and Malecki (2004); there is little evidence indicates that informal network used by institution relative was little or seek the development of these formal chains, to can construct development strategy institutions, by doing identification barriers exist, so that the formal chain superior can be very crucial for increasing competitiveness institution. On the research pertaining to competitiveness higher education institutions which analyses orientation marketing and quality service by Stimac and Simic (2012), declare that potential increase competitive position in the market higher education with concerning the aspect of imagery good and a reputation in the local environment and have identified force institution on quality lecture, sources studies, cooperation with similar institutions.

This research result supported also with research conducted by Meyer et, al, (2013) found that the act of purchasing by the consumer into focus institutions could perceived level benefits and loyalty that varies according to the orientation purchase done by consumers. Then research findings pertaining to loyality consumers aircraft according to Anuwichanont (2011) brand trust decisively predict second attitudes and behavior loyality significantly. Even though the study in the retail sector against loyality consumers in purchase, Meyer (2008) that findings of research need confirmation in the retail sector another before they can be perceived fully generalisable. Retailers in an effort to segments market target, that allows expenditure their marketing more effectively. The study was contributes to knowledge rather generalisable by an investigate about loyalty purchase, competitive program and storage locations on the broader market.

Such an higher education institutions that administers programs graduate started to develop strategy to enter global market, to compete necessary marketing strategies, as on the outcome of thought White and Griffith (1997), development strategies to global competitiveness to an organization for global market in competitive, must choose and implementing a marketing strategies compatible with institutions strategy. To operate in global market had to develop a bond in which synergistic between marketing strategies and institutions. Through a strategy a viable combination, could maximize competitive advantage, allowing to compete effectively and efficiently into the world. Subsequently to can connect with consumers, then institutions could conducted with application internet can reach consumers quickly and build consumers chains as fast as possible with program marketing of institutions, because consumers using devices mobile internet to seek service institution of higher education. A threat most dangerous on an institution is market position is competition, especially of an institution of private higher education more flexible and oriented market. Understand value and importance marketing unique on the application in higher education is a prerequisite for performance marketing which succeeds, dynamic because of a change in value of all stakeholders, requirements and needs.

\section{Concluding Remarks}

Based on the result analysis and discussions on the conclusion in research were: 1). Distribution of respondents in research is composed of some male $=40 \%$, female $=60 \%$. Income levels $(\geq 5$ million IDR $=61.90 \%)$ and it ( $<5$ million IDR $=38.10 \%$ ) and average age of respondents 32.80 years with $S D=7.32$, could be basic for made marketing action plan on higher education institutions. 2). Variable of communitization marketing 3.0 was confirmed on an act of customers purchasing in institutions of postgraduate in Jakarta.

Such an implications of the research can be the policy institution for direction priority development and marketing strategies to be implemented pertain : 1). Increase brand equity institutions in higher education, more connection between students, creating more customers loyalty, institution in higher education must making space for customers 
connection and encouragement sustainable customers connection each others, however all indicators were correlated with believed in a postgraduate credible institutions in Jakarta. 2). Increase encouragement decision on the consumer purchases through institutions of the higher education competitive to consumer who was a believed in a postgraduate credible institutions in Jakarta. 3). The customers act of decision increase purchase through process that saves time, transactions simple and full of easier movement and tactics promotion were reliable about the potential consumers who interact and creates customer base that loyalty.

\section{References}

Anuwichanont, Jirawat, PhD. (2011). "The Impact Of Price Perception On Customer Loyalty In The Airline Context ", Journal of Business \& Economics Research Vol.9. Issue 9 p.: 37-49. http://search.proquest.com/docview/ 892713889?accountid=34643.

Bennett, Anthony G. (2010). The Big Book of Marketing, Lessons and Best practices from the World's Greatest Companies, New York, The McGraw -Hill Companies.

Cravens, David W dan Piercy, Nigel F. (2006), Strategic Marketing, Eight Edition, New York, The McGraw -Hill Companies.

Curtis, Tamilla; Abratt, Russell, Rhoades, Dawna, Dion, Paul. (2011), CUSTOMER LOYALTY, REPURCHASE AND SATISFACTION: A META-ANALYTICAL REVIEW, Journal of Consumer Satisfaction, Dissatisfaction and Complaining Behavior Vol. 24, p: 1-26. http://search.proquest.com/ docview/923772312? accountid=34643.

Diposumarto, Ngadino Surip. (2012). METODOLOGI PENELITIAN: Teori dan Terapan, Jakarta: Penerbit Mitra Wacana Media.

Diposumarto, Ngadino S dan Susilo, Wilhelmus H. (2013). RISET PEMASARAN: Aplikasi Dengan SPSS, LISREL \& AMOS Pada Penelitian Peamasaran Jasa, Jakarta: Penerbit IN Media.

Goebel, Daniel J; Marshall, Greg W; Locander, William B. (2013), Enhancing purchasing's strategic reputation: Evidence and recommendations for future research, Journal of Supply Chain Management $39.2: 4-14$.

Griffin, Ricky W dan Ebert, Ronald J. (2007). BISNIS, Edisi Kedelapan, Jilid 1, Jakarta: Penerbit Erlangga.

Griffin, J. (2003). Customer loyalty: Menumbuhkan dan Mempertahankan Kesetiaan Pelanggan, Alih bahasa: Dr Dwi Kartini Yahya, Jakarta, Penerbit Erlangga.

Hair, Joseph, F., Anderson, Rolpp E., Tatham Ronald, L, Black, William, C.(1998). Multivariate Data Analysis, Prentice Hall, Third Edition, 1998.

Kingsley, Gordon dan Malecki, Edward J. (2004), "Networking for Competitiveness", Small Business Economics 23.1 : 71-84. , http://search.proquest.com/docview/220955590?accountid=34643.

Kotler, Philip and Keller Kevin L. (2013). MARKETING MANAGEMENT, Fourteenth Edition, Horizon Edition, England PEARSON Education Linited.

Kotler, Philip and Kartajaya, Hermawan, Marketing 3.0, Jakarta, Penerbit Erlangga, (2010).

Limakrisna, Nandan dan Susilo, Wilhelmus Hary, (2012), MANAJEMEN PEMASARAN, Teori dan Aplikasi dalam Bisnis, Jakarta: Penerbit Mitra Wacana Media.

Lovelock, Christopher et al. (2012). Pemasaran Jasa, Manusia, Teknologi, Strategi, Perspektif Indonesia, Jilid2, Edisi Ketujuh. Jakarta. Penerbit ERLANGGA

Meyer-Waarden, Lars. (2008), "The influence of loyalty programme membership on customer purchase behavior", European Journal of Marketing, Volume . 42, Issue . 1/2, Pages . 87-114, http://dx.doi.org/ 10.1108/03090560810840925.

Meyer-Waarden, Lars; Benavent, Christophe; Castéran, Herbert. (2013), "The effects of purchase orientations on perceived loyalty programmes' benefits and loyalty", International Journal of Retail \& Distribution Management, Vol.41.Issue.3 : 201-225. http:/l search.proquest.com / docview/ 1315333092 ? accountid=34643.

Schiffman, Leon and Kanuk, Leslie Lazar. (2008), PERILAKU KONSUMEN, Edisi Ketujuh, Jakarta, PT INDEKS.

Scott, David M. (2011), The New Rules of Marketing \& PR, New Jersey, John Wiley \& Sons, Inc.

Stimac, Helena; Simic, Mirna Leko. (2012), "COMPETITIVENESS IN HIGHER EDUCATION: A NEED FOR MARKETING ORIENTATION AND SERVICE QUALITY", Economics \& Sociology 5.2 : 23-34,153. http://search.proquest.com/ docview/1268704687? accountid= 34643 .

Susilo, Wilhelmus H dan Yulius, Yudi. (2013). Marketing Bisnis Jasa, Peran Orientasi Pelanggan, Building Character Terhadap Tingkat Daya Saing Institusi: Teori dan Aplikasi SPSS \& LISREL pada Riset Pemasaran. Jakarta. IN Media.

Viacava, Keitiline Ramos and Pedrozo, Eugenio Avila. (2010)." Higher Education in management: reinventing the paradigm to gain the capacity to handle today's complexity", On the Horizon, Vol.18 Iss:1, pp.45- 52. http://www.emeraldinsight.com/jornal.htm?issn= 1047- 8121\&volume $=18 \& i s s u e=1 \&$ articleid $=1838391 \&$ show=abstract.

Wang, Yonggui dan Lo, Hing-Po, (2004), "Customer-Focused Performance and Its Key Resources-Based Determinats: An Integrated Framework", Competitiveness Review: An International Business Journal incorporating Journal of Global Competitiveness, Vol.14 Iss:1/2, pp34-59, http://www.emeraldinsight.com /jornal.htm?issn=10595422\& volume=14\&issue=1/2\& articleid=1669084\& show=abstract.

White, D Steven, Griffith, David A. (1997), "Combining corporate and marketing strategy for global competitiveness", Publication title, Marketing Intelligence \& Planning, Vol.15. Issue. 4 pp: 173. http://search.proquest.com/ docview/213124472?accountid=34643.

Wijanto, Setyo H. (2008). Structural Equation Modeling dengan LISREL 8.8, KONSEP \& TUTORIAL. Jakarta, Penerbit Graha IImu.

Wright, Robert E. (2012), "Marketing Orientations and Higher Education: Applications and Implications", The Journal of Applied Business and Economics, Volume .13, Issue . 5, pp. 53-57. http://search.proquest.com/docview/1315304178?accountid=34643. 